\title{
長期食塩過㮃捸取による血圧上昇に対する 交感神経活性え進並びに腎ドーパミン受容体減少の意義
}

\author{
福息医大第三内科 \\ 重 富秀一, 上野修一, 戸崎英夫 \\ 鴻野浩, 橋本重厚, 福地総逸 \\ Increased the Activity of Sympathoadrenomedullary System \\ and Decreased Renal Dopamine Receptor Contents after \\ Short-term and Long-term Sodium Loading in Rats

\section{Shuichi SHIGETOMI, Shuichi UENO, Hideo TOSAKI, Hiroshi KOHNO, Shigeatsu HASHIMOTO and Soitsu FUKUCHI}

\author{
The Third Department of Internal Medicine, \\ Fukushima Medical College \\ Correspondence: Shuichi Shigetomi; \\ The Third Department of Internal Medicine, \\ Fukushima Medical College, \\ 4-45 Sugitsuma Cho, Fukushima Shi, \\ Fukushima, Japan 960
}

We investigated the effects of short-term and long-term sodium loading on the sympathoadrenomedulary system and renal dopamine receptor. Male Wistar rats $(n=30)$ were raised drinking $1 \% \mathrm{NaCl}$ for four weeks. Urinary norepinephrine and epinephrine excretion (UNE and UE) were measured before and 1,2, 4 weeks after sodium loading by the use of high pressure liquid chromatography with fluorescence spectrophotometer. Renal plasma membranes were prepared by the ultracentrifugation method, and maximal binding capacity (Bmax) and dissociation constant $(\mathrm{Kd})$ of renal dopamine receptor were determined by Scatchard analysis using 3-H-spiperone.

Results: Sodium loading caused a slight but not significant decrease of free UNE after 1 and 2 weeks then clear increments of total (free + conjugated) UNE, free UE and total UE after 4 weeks. Bmax of renal dopamine receptor did not change after 1 and 2 weeks but significantly decreased after 4 weeks (before: $535.9 \mathrm{fmol} / \mathrm{mg}$ protein, after 4 weeks: $327.2 \mathrm{fmol} / \mathrm{mg}$.protein). $\mathrm{Kd}$ of renal dopamine receptor slightly elevated 1 week after sodium loading and then returned to the initial level.

Conclusion: These data suggest that short-term sodium loading may suppress the sympathetic activity, but long-term sodium loading may increase the activity of the sym- 
pathoadrenomedullary system with the decrease of renal dopamine receptor concentration. Increased catecholamines and decreased renal dopamine after long-term sodium loading may contribute to sodium-dependent hypertension.

\section{緒}

言

カテコールアミンは腎における水・電解質代謝に関与し, 高血圧の発症と維特に重要な役割を演

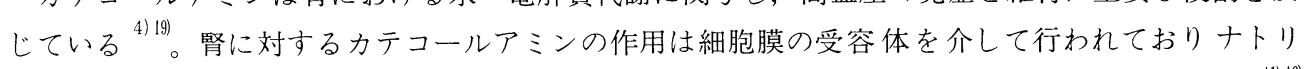
ウム再吸収に対して $\alpha$ 拈び $\beta$ 受容体は促進的に, dopamine 受容体は抑制的に働くと考えられている(1) (6)

食塩負荷時には, ドーパミン活性が立進する ${ }^{5)}$ ともに交感神経系が抑制される ${ }^{14}$ ので, 体液貯 留による血圧上昇が弱められると言われるが, その詳細な機序は不明であり, 食塩負荷を長期間持 続した場合の交感神経系の変化についても明らかでない。そこで, 食塩過剩摂取時の血圧上昇に対 する交感神経・副腎髄質系並びに腎ドーパミン受容体の役割を明らかにするため, 以下の検討を行 つた。

\section{実 験 方 法}

ウィスター系成熟雄ラット（体重250-300 g ) 30匹を $1 \% \mathrm{NaCl}$ 投与下で 4 週間飼育し, 食塩水負 荷前㧍よび負荷後 $1 ， 2 ， 4$ 週目に代謝ケージを用いて 24 時間尿を採取してカテコールアミン排泄 量を測定するとともに，各週齢のラットを pentobarbital 麻酔後開腹し， $0.85 \% \mathrm{NaCl}$ にて腎を潅流 後摘出，腎の細胞膜を分離して腎のdopamine 受容体の解析を行った。

\section{カテコールアミンの測定}

遊離型カテコールアミンは以下の方法で抽出し測定した。即ち, 塩酸を加えて $\mathrm{pH} 1.0$ 以下とした 尿 $1.0 \mathrm{ml}$ に対し活性アルミナ200mg と $2.5 \% \mathrm{EDTA}-2 \mathrm{Na}$ を含む $1.5 \mathrm{M}$ tris 緩衝液, $\mathrm{pH} 8.6$ を $1 \mathrm{ml}$ 加 えて 5 分間振盪後, 蒸留水 $(10 \mathrm{ml})$ でアルミ十を三回洗浄し, 次いで $0.1 \mathrm{~N}$ 過塩素酸 $1.0 \mathrm{ml}$ を加之 て再度 5 分間振盪してアルミ十に吸着したカテコールアミンを溶出, 溶液中のカテコールアミン含 量を蛍光反応システムを備えた高速液体クロマトグラフィーにより測定した。また，総カテコール アミン (遊離型＋抱合型) は前述の酸性尿 $1 \mathrm{ml}$ をwater bath中で15分間煮沸してのち同様の方法 にて抽出後測定した。

\section{ドーパミン受容体の解析 ${ }^{23}$}

摘出した腎の被膜並びに腎う・腎杯を除去後細片とし， 5 倍量の $30 \mathrm{mM} \mathrm{d,l-histidine,} 200 \mathrm{mM}$ sucrose, $5 \mathrm{mMEDTA}-2 \mathrm{Na}$ を含む $18 \mathrm{mM}$ tris 緩衝液, pH 7.4を加えて homogenizeした。これを, $200 \times \mathrm{G}$ で15分間, 次いで $10,000 \times \mathrm{G}$ で30分間遠心し, 沈さを除去後, 上清を $48,000 \times \mathrm{G}$ で 60 分間 遠心し, 得られた沈さに $10 \mathrm{mM} \mathrm{MgCl}$ 2を含む $50 \mathrm{mM}$ tris 緩衝液, pH7.4 (assay buffer) )加えて 浮遊させ，これを細胞膜として用いた。

次に，この受容体 $100 \mu \mathrm{l}$ (蛋白量200-400 $\mu \mathrm{g} / \mathrm{tube}$ ) に対し, 3-H-spiperone (10 - 300nM) $100 \mu \mathrm{l}$ を加えてのち， assay buffer にて全量を $300 \mu \mathrm{l}$ に調整後， $37^{\circ} \mathrm{C} て ゙ 15$ 分間incubate した。反応終了 後直ちに氷冷したassay buffer $2 \mathrm{ml}$ を加えてのち, Whatman GF/C glass fiber filterにて受容体 と結合した3-H-spiperone を分離採取し, 前述のassay buffer $(10 \mathrm{ml})$ でglass fiber filter 二回 洗浄後, filter をカウンティングバイアルに移し，その放射活性を液体シンチレーションカウンタ 
一により測定した。受容体の最大結合能と解離定数はScatchard plot 法により解析した。また， 受容体に対する 3-H-spiperoneの非特異的結合は非標識ドーパミン $(10 \mathrm{mM})$ を100 $\mu \mathrm{l}$ 添加した時 の結合量とした。

\section{実 験 結 果}

食塩負荷による尿中カテコールアミン排泄量の変化

尿中遊離型ノルエピネフリン排泄量は $0.21 \pm 0.19 \mu \mathrm{g} /$ 日 (平均值士標準偏差) より食塩負荷 1 週 後 $0.17 \pm 0.30 \mu \mathrm{g} /$ 日， 2 週後 $0.09 \pm 0.08 \mu \mathrm{g} /$ 日と軽度に減少したが，統計学的に有意差はなかった。 しかし， 4 週後には $0.66 \pm 0.33 \mu \mathrm{g} /$ 日と負荷前に比べ明らかに増加した $(\mathrm{p}<0.001)$ 。また，総）

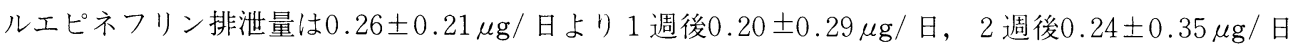
と有意の変化を示さなかったが， 4 週後には $1.37 \pm 1.04 \mu \mathrm{g} /$ 日と著明に増加した $(\mathrm{p}<0.001)$

(Fig. 1)。

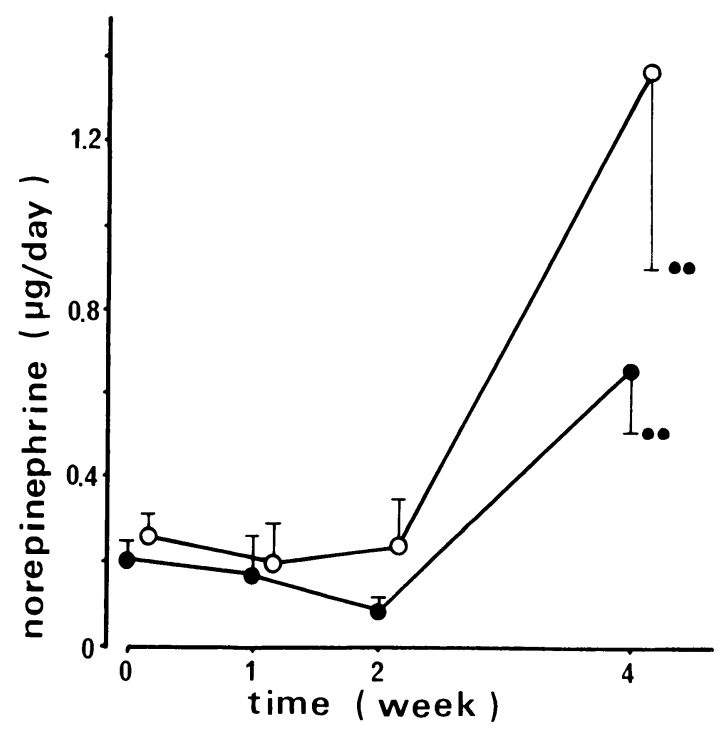

Fig. 1. Urinary free and total (free + conjugated) norepinephrine excretion before $(n=15)$ and $1(n=10), 2(n=10)$ and 4 weeks $(n=5)$ after sodium loading. Values represented by closed circle $(\bullet)$ and open circle (o) indicates free and total norepinephrine excretion, respective-

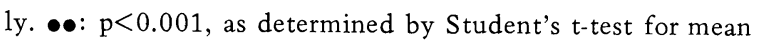
differences.

尿中遊離型エピネフリン排泄量は $0.02 \pm 0.03 \mu \mathrm{g} /$ 日より， 1 週後 $0.00 \pm 0.00 \mu \mathrm{g} /$ 日, 2 週後 0.01 $\pm 0.02 \mu \mathrm{g} /$ 日と有意の変化を示さなかったが，4週後には0.12 $00.05 \mu \mathrm{g} /$ 日に増加した。また，総

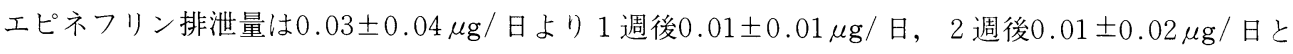

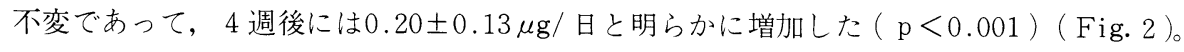




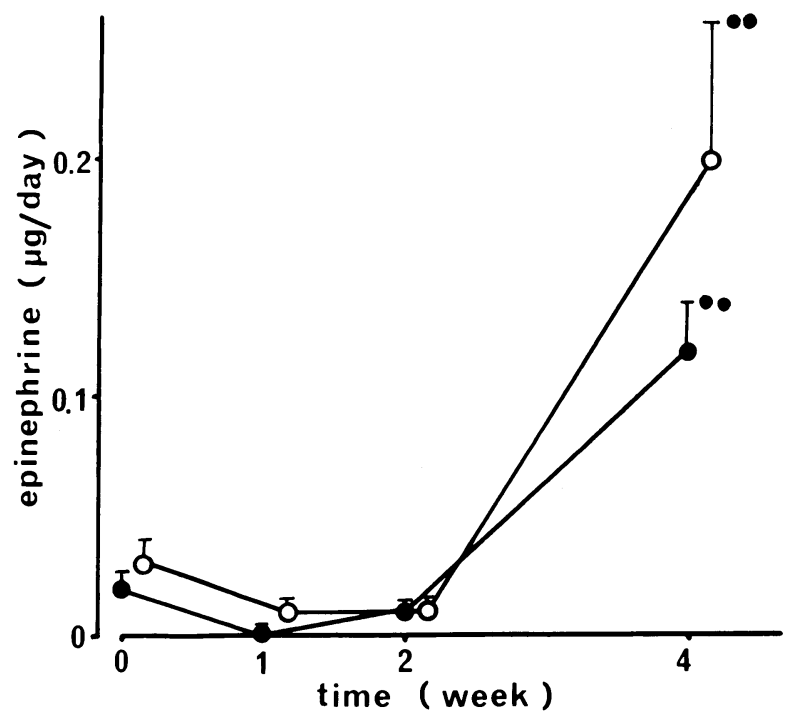

Fig. 2. Urinary free and total (free + conjugated) epinephrine excretion before $(n=15)$ and $1(n=10), 2(n=10)$ and $4(n=5)$ after sodium loading.

Values represented by closed circle $(\bullet)$ and open circle (o) indicates free and total epinephrine excretion, respectively. $\bullet \bullet: \mathrm{p}<0.001$, as determined by Student's t-test for mean differences.
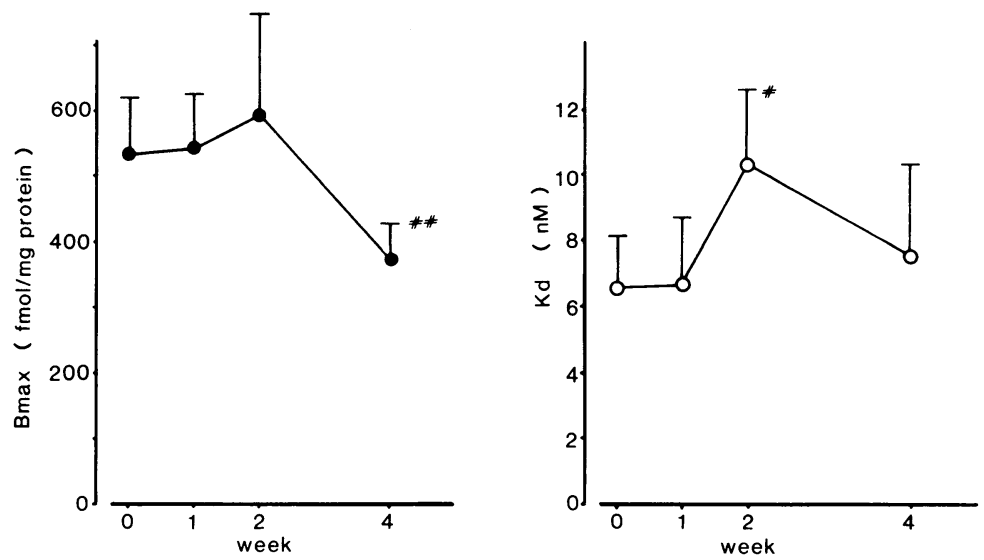

Fig. 3. Maximal binding capacity (Bmax) and dissociation constant (Kd) of renal dopamine receptor.

Values represented by closed circle $(\bullet)$ and open circle $(0)$ indicates Bmax and Kd, respectively.

Bars represent one SEM (before; $n=10,1$ week; $n=5,2$ weeks; $n=10$ and 4 weeks; $\mathrm{n}=5$ )

$\#: \mathrm{p}<0.1, \#: \mathrm{p}<0.05$, as determined by Student's t-test for mean differences. 


\section{食塩負荷による腎ドーパミン受容体の変動}

腎ドーパミン受容体の最大結合能は $535.9 \pm 85.6 \mathrm{fmol} / \mathrm{mg}$ ・蛋白 $(\mathrm{n}=10)$ より, 1 週後 $543.4 \pm 84.0$ $\mathrm{fmol} / \mathrm{mg}$ ·蛋白 $(\mathrm{n}=5), \quad 2$ 週後 $594.9 \pm 159.3 \mathrm{fmol} / \mathrm{mg}$ ・蛋白 $(\mathrm{n}=10)$ と有意の変化を示さなかっ たが， 4 週後には $327.2 \pm 56.6 \mathrm{fmol} / \mathrm{mg}$ ・蛋白 $(n=5)$ と明らかに減少した $(\mathrm{p}<0.05)$ 。また，解 離定数は $6.6 \pm 1.5 \mathrm{nM}$ 上り，1 週後は $6.7 \pm 2.0 \mathrm{nM}$ と不変， 2 週後 $10.3 \pm 2.3 \mathrm{nM}$ と軽度に上昇した

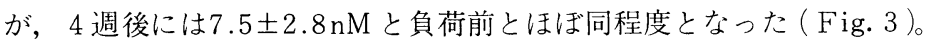

\section{考案}

交感神経系は腎におけるナトリウム代謝と密接な関連を有している。食塩攝取量を著しく制限す ると腎神経の活動電位が高まると同時にナトリウムの排泄量は減少するが, 腎神経を除去すると,

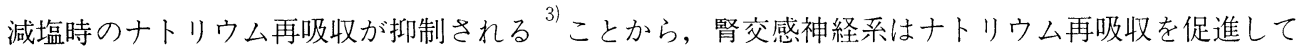
体液を保持するように働くと考えられる。

本実験により，短期の食塩負荷では尿中遊離型ノルエピネフリンの減少を認めたが, 長期の負荷 では遊離型並びに総ノルエピネフリンおよびエピネフリンがともに增加したことから, 短期食塩負 荷時には末梢交感神経系が軽度に抑制されるが, 負荷が長期にわたると交感神経終末のみならず副 腎髄質からのカテコールアミン分泌が艺進すると思われる。

食塩負荷時には交感神経系の活動性が変化すると言われている。Luft ら ${ }^{14)}$ は, 食塩捸取量を短 期間変化させると, 尿中ナトリウム排泄量と 24 時間尿中ノルエピネフリン排泄量とは負の, 平均血 圧および心拍出量とは正の相関を示すことより，食塩負荷後にはbaroreceptorを介して交感神経系 が抑制されると結論した。また，正常者に高張食塩水を投与すると血中メタネフリン含量が低下す る ${ }^{22)}$ ので, 短期の食塩負荷時には, 交感神経・副腎髄質系の活性が抑制され, 血圧の上昇を阻止す るように働くと思われる。一方, 長期食塩負荷時にカテコールアミンが増加する機序についての詳 細は現在のところ不明である。最近, 心不全や妊娠後期の症例あるいは生理食塩水の点滴静注後に はドーパミン ${ }^{918)}$ ，内因性ジギタリス様物質， ${ }^{8101317)}$ 心房性ナトリウム利尿因子 ${ }^{23}$ など複数の利尿 因子が増加することが，明らかとなった。これらの利尿因子のうち，内因性ジギタリス様物質は細 胞膜の $\mathrm{Na}^{+}-\mathrm{K}^{+} \mathrm{ATP}$ a se 活性を阻害するので, 交感神経終末や副腎髄質から放出されるカテコールア ミンの re-uptakeを抑制することによりカテコールアミンを増加させる可能性がある。また，D O $\mathrm{CA}$ 食塩高血圧ラットでは, 脳幹部の抑制性交感神経線維の活性が低下することにより末梢交感神 経系が緊張することが明らかにされており， ${ }^{2)}$ 長期食塩負荷時の交感神経・副腎髄質機能立進には 中枢神経系も一部関与する可能性がある。

腎には $\alpha, \beta$ 受容体およびdopamine に対する特異的受容体が存在しており， ${ }^{2012123244)}$ カテコールア ミンの作用はこれらの細胞膜受容体との結合によって発現することが明らかにされた。食塩負荷な ど体液量が増加する条件下では腎のドーパミン合成が促進し，腎血流量の増加 ${ }^{15}$ とともに近位尿細 管でのナトリウム再吸収が低下 ${ }^{1)} し$ ，ナトリウム利尿を来たす。ドーパミンの腎に対する生物学的 効果は, 合成されたドーパミン量と主として近位尿細管に存在する受容体 ${ }^{6) 7}$ の数とにより変化す ると考えられるが，食塩負荷に伴う腎ドーパミン受容体の経時的変化については不明であった。

本実験により，腎ドーパミン受容体のホルモンに対する親和性は食塩負荷後一過性に低下しての ち回復すること, また, 単位蛋白量当たりの受容体数は食塩負荷初期には変化しないが負荷が続く と減少することが明らかとなった。食塩負荷後の親和性の低下は内因性ドーパミンと腎の受容体と 
の結合による細胞膜構造の一時的な変化に基づくと考えられる。一方, 長期食塩負荷によるドーパ ミン受容体数減少の理由としては, 腎におけるドーパミン合成促進による down regulationの他に,

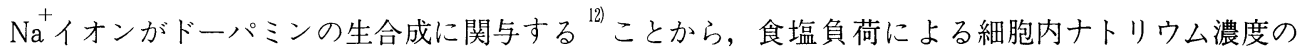
上昇によって腎ドーパミン受容体の数が変化する可能性もある。前述のごとく, 食塩負荷時にはド 一パミン活性の元進によってナトリウム排泄が増加し体液貯留を抑制するが, 食塩負荷が長期に及 ぶとドーパミンの増加にも拘わらずドーパミン受容体数の減少によって，ドーパミンの堅に対する 効果が減弱すると考えられる。

従来より，食塩負荷のみでは血圧は上昇せず，食塩とともに鉱質ステロイドや抗ドーパミン剂を 投与すると高血圧を発症することが知られている。食塩過剩摂取のみでは著しい血圧上昇を来たさ ない理由として, 交感神経系やレニン・アンジオテンシン系の抑制, カリクレイン・キニン系の立 進の他に，未知の利尿因子の増加が考えられており，今回の成績でも食塩負荷初期には交感神経の 抑制と腎ドーパミン活性の充進を認めた。しかし，前述のごとく，長期食塩負荷時には，交感神経・ 副腎髄質系の充進と腎ドーパミン受容体数減少によるドーパミンの腎に対する効果の減弱を来たす ので，種々の刺激に対して血圧が上昇し易い状態になると思われる。

\section{結語}

食塩負荷に伴う交感神経・副腎髄質系の経時的変化と腎ドーパミン受容体の変動との関連を明ら かにするため, ウィスター系雄ラット30匹を $1 \%$ 食塩水投与下で 4 週間飼育し，尿中カテコールア ミン排泄量を高速液体クロマトグラフィーにて測定するとともに，1，2，4 週後に腎を摘出， radioligand binding 法により腎ドーパミン受容体の解析を行い, 以下の結果と結論を得た。

1）尿中遊離型ノルエピネフリン排泄量は食塩負荷 1,2 週後に軽度低下したが，4 週後には著 明に増加した。また, 総 (遊離型十抱合型) ノルエピネフリン排泄量は 1,2 週後は不変, 4 週後 には明らかに増加した。

2）尿中遊離型および総エピネフリン排泄量は $1 ， 2$ 週は有意の変化を示さず， 4 週後には明ら かに増加した。

3）腎ドーパミン受容体の最大結合能は $1 ， 2$ 週後は有意の変化を示さなかったが， 4 週後には 有意に減少した。また, 解離定数は 1 週後は不変, 2 週後に軽度高值を呈してのち，4 週後には負 荷前と同程度となった。

以上の成績より, 食塩摂取過剩が長期間つづくと, 交感神経・副腎䯣質系の充進と腎ドーパミン 受容体数の減少によって, 心・血管系の緊張とナトリウム利尿効果の抑制を来し, 血圧が上昇し易 い状態になると思われる。

本研究の一部は千代田生命健康開発事業団「社会厚生事業助成」の援助によった。

\section{文献}

1) Bello-Reuss, E., Higashi, Y. and Kaneda, Y.: Dopamine decreases fluid reabsorption in straight portions of abbit proximal tubule. Am. J. Physiol., 242: F634-F640, 1982.

2) Charmers, P.: Brain amines and models of experimental hypertension. Circ. Res., 36: 
469-480, 1975.

3) Dibona, G.F.: Catecolamines and neuroadrenergic control of renal function. p.323-p.366, Ed. by Dunn, M.J., Renal Endocrinology, Williams \& Willkins, Ltd., Baltimore, USA, 1983.

4) Dibona, G.F.: Neurogenic regulation of renal tubular sodium reabsorption. Am. J. Physiol., 233: F73-F81, 1977.

5) Faucheux, B., Buu, N.T. and Kuchel, O.: Effects of saline and albumin on plasma and urinary catecholamines in dog. Am. J. Physiol., 232: F123-F127, 1977.

6) Felder, R.A., Blecher, M., Eisner, G.M. and Jose, P.A.: Cortical tubular and glomerular dopamine receptors in the rat kidney. Am. J. Physiol., 246: F557-F568, 1984.

7) Felder, R.A., Blecher, M., Calcagno, P.L. and Jose, P.A.: Dopamine receptors in the proximal tubule of the rabbit. Am. J. Physiol., 247: F499-F505, 1984.

8) Graves, S.W. and Williams, G.H.: An endogeneous ouabain-like factor associated with hypertensive pregnant woman. J. Clin. Endocrinol. Metabol., 59: 1070-1074, 1984.

9）春山和見, 重富秀一, 山崎正明, 柳沼健之, 福地総冕: 本態性高血圧症の食塩感受性とドーパミン分泌 との関連。日内泌会誌， 59: 1658-1666, 1983.

10) 一二三宣秀, 三船順一郎, 高橋

美文, 清水健己, 多賀邦章, 田中 孝, 森瀬敏夫, 宮森 勇, 竹田亮祐：うっ血性心不全における十トリウ 么利尿因子。医学のあゆ, 134: 1173-1174, 1985.

11) 飯野靖彦：カテコールアミ ンと電解質移送系。日本臨床， 41：146-155， 1983.

12) Imbs, J.L., Schmidt, M., Ehrhart, J.D. and Schwart, J.: Sympathetic nervous system and renal sodium handling: Is dopamine involved? J. Cardiovasc. Pharmacol., 6 (Suppl. I): S171-S175, 1984.

13）小島 至, 尾形悦郎：内因性 digitanis 様物質。日本臨床, 42: 298-305, 1984.

14) Luft, F.C., Rankin, L.I., Henry, D.P., Bloch, R., Grim, C.E., Weyman, A.E., Murry, R.H., Plasma and urinary norepinephrine values at extremes of sodium intake in normal man. Hypertension, 1: 261-266, 1979.

15) McDonald, R.H., Goldberg, L.I., McNay, J.L. and Tuttle, E.P.: Effect of dopamine in man, agumentation of sodium excretion glomerular filtration rate and renal plasma flow. J. Clin. Invest., 43: 1116-1124, 1964.

16) Oliver, J.A., Pinto, J., Sciacca, R.R. and Cannon, P.J.: Increased renal secretion of norepinephrine and prostaglandin E2 during sodium depletion in the dog. J. Clin. Invest., 66: 748-756, 1980.

17) Plunkett, W.C., Hutchins, P.M., Gruber, K.A. and Buckalew, V.M.: Evidence for a vascular sensitizing factor in plasma of saline-loaded dogs. Hypertension, 4: 581-589, 1982.

18) 志熊利枝子, 寒原誠一, 吉村 学, 高階良作, 山崎英彰, 竹田和夫, 高橋伯夫, 伊地知浜夫 : 食塩感受性高血圧に扔ける dopamine の役割。日腎誌, 26: 417-423, 1984.

19）重富秀一：本態性高血圧症の発症および進展における中枢並びに末 梢交感神経系とレニン・アルドステロン系の役割に関する研究。日内泌会誌, 59: 1829-1844, 1983.

20）重富秀一, 橋本重厚, 佐藤啓二, 佐藤 衛, 上野修一, 国井伸泰, 戸崎英夫, 福地総冕: Radioreceptor assayによる腎交感神経系 $\alpha$ および $\beta$ 受容体の解析。日腎誌, 26: 1355-1360, 1984.

21）重富秀一, 橋本重厚, 上野修一, 鴻野 浩, 戸崎英夫, 福地総逸：Radioligand binding 法による腎 dopa mine 受容体の検討。医学のあゆみ, 133: 533-534, 1985.

22) 重富秀一, 上野修一,

橋本重厚, 佐藤 衛, 佐藤啓二, 鴻野 浩, 戸崎英夫, 福地総冕, 飯沼一茂：本態性高血圧症の血漿及び尿 中メタネフリン含量。日腎誌，27: 833-838, 1985.

23) 重富秀一, 上野修一, 鴻野 浩,

戸崎英夫, 末永一人, 橋本重厚, 福地総冕：食塩負荷時の血圧上昇に対する腎ドーパミン受容体の役割。日 
内分泌会誌, 62: 26-33, 1986.

24) Summers, R.J. and McPherson, G.A.: Radioligand studies of adrenoceptors in the kidney. p.54-p.59, Ed. by Lamble, J.W. and Abbott, A.C., Receptors Again, Elsevier, Ltd., New York, USA, 1984.

25) 山路 徹, 石橋

みゆき, 長谷部弘一, 森井浩世：病態に打ける心房性ナトリウム利尿ホルモンの血中濃度について。日内泌 会誌, 61: 1090, 1985.

（受付日; '85。12.26） 